Int. J. Morphol.,

36(1):206-211, 2018.

\title{
Effects on Alveolar Bone of Diabetes Mellitus Induced by Streptozotocin in Rats. Histopathologic and Immunohistochemical Study
}

\author{
Efectos de la Diabetes Mellitus Inducida por Streptozotocina en el \\ Hueso Alveolar de Ratas. Estudio Histopatológico e Inmunohistoquímico
}

\begin{abstract}
Nezih Yilmaz'; Ibrahim Uysal²; Veysel Eratilla ${ }^{3}$; Irtegün Sevgi ${ }^{4}$; Rojdan Ferman Günes Uysal'; Elif Eratilla ${ }^{5}$; Elbey Hüseyin ${ }^{6}$; Uysal Ersin ${ }^{7}$; Busra Deveci ${ }^{8}$ \& Engin Deveci ${ }^{9}$
\end{abstract}

YILMAZ, N.; UYSAL, I.; ERATILLA, V.; SEVGI, I.; GÜNES UYSAL, R. F.; ERATILLA, E.; HÜSEYIN, E.; ERSIN, U.; DEVECI, B. \& DEVECI, E. Effects on alveolar bone of diabetes mellitus induced by streptozotocin in rats. histopathologic and immunohistochemical Study. Int. J. Morphol., 36(1):206-211, 2018.

SUMMARY: The purpose of this study was to investigate effects of diabetes mellitus (DM) on the alveolar bone with histopathological and immunohistochemical methods. Wistar rats were divided into two groups, control and diabetes group. Control group was fed standard rat chow and drinking water for 8 weeks. Single dose (Streptozotocin) STZ (55 mg/kg), was dissolved in sodium citrate buffer and introduced intraperitoneal injection. Diabetes group and control group were compared in terms of glucose values. The blood glucose concentration in diabetic rats was significantly high $(\mathrm{p}<0.05)$. In diabetes group; periodontal membrane and the dilation of blood vessels, hemorrhage has also been a significant increase in inflammatory cells. In the diabetes group, osteonectin showed positive expression in periodontal membrane and showed negative expression in osteocytes of alveolar bone. Osteopontin expression in fibroblast cells and periodontal membrane collagen fibrils was positive, alveolar cells, osteocytes and bone matrix bone was found positive. Diabetes results showed that there formed periodontitis; due to the increase in inflammation inhibiting bone formation delaying the development of early bone cells.

KEY WORDS: Alveolar bone; Diabetes mellitus; Rat; Osteonectin; Osteopontin.

INTRODUCTION

Diabetes mellitus is a disease in which carbohydrate, protein and lipid metabolism homeostasis are inadequately regulated by the pancreatic hormone, insulin, resulting in an increase in blood glucose levels (Sunil et al., 2011). Type 2 diabetes mellitus (T2DM) is a multiple risk factor disease, and dyslipidemia, hyperglycemia and visceral obesity are the major determinants (Preshaw et al., 2012). Periodontal diseases are the six most common co-morbid condition in patients with diabetes mellitus (Löe, 1993; Al-Maskari et al., 2011) and evidence indicates a bidirectional relationship between these two pathologies (Lakschevitz et al., 2011;
Awuti et al., 2012). The presence of diabetes influences the periodontal tissues by altering neutrophil function and collagen synthesis, inducing vascular abnormalities through genetic predisposition (Oliver \& Tervonen, 1994). Relationship between diabetes and periodontitis is thought to be due to changes occurring in the alveolar bone structure. Osteopontin (OPN) is considered to play important roles in promoting or regulating the adhesion, attachment, and spreading of osteoclasts to bone surfaces during bone resorption (Reinholt et al., 1990; Ikeda et al., 1992). OPN blood levels in diabetic patients are known to be higher than

\footnotetext{
${ }^{1}$ Department of Endodontics, Diyarbakır Oral and Dental Health Center, Turkey.

${ }^{2}$ Department of Prostodontics, Diyarbakır Oral and Dental Health Center, Turkey.

${ }^{3}$ Department of Medical Biology, Faculty of Medicine, University of Dicle, Diyarbakir, Turkey.

${ }^{4}$ Department of Oral Surgery, Dental Faculty, Dicle University, Turkey.

${ }^{5}$ Department of Operative Dentistry, Dental Faculty, Dicle University, Turkey.

${ }^{6}$ Department of Plastic surgery, Faculty of Medicine, University of Dicle, Diyarbakir, Turkey

${ }^{7}$ Dicle University, Vocal Sch.Tech.Sci.Diyarbakır, Turkey.

${ }^{8}$ Diyarbakır Oral and Dental Health Center, Diyarbakır, Turkey.

${ }^{9}$ Department of Histology, Medicine Faculty, Dicle University, Turkey.
} 
in normal individuals (Yan et al., 2010). (Adiponectin) APN is an important inflammatory molecule which modulates insulin resistance associated with a response (Ninomiya $e t$ al., 2007). Osteonectin is a $32 \mathrm{kDa}$ phosphorylated glycoprotein that binds simultaneously to type I collagen and hydroxyapatite (Barrett-Connor \& Holbrook, 1992), and is localized at osteoblasts and odontoblasts (Hamann et al., 2012). In this study that we aim to investigate the effects of streptozotocin-induced diabetes mellitus of histopathological and immunohistochemical changes on alveolar bone in rats.

\section{MATERIAL AND METHOD}

The present work was conducted in accordance with the guidelines for the Care and Use of Laboratory Animals from the Dicle University. The study was conducted as per approval of the Animal Experiments Local Ethics Committee, Dicle University. Experimental Animal Research Center 20 adult male Wistar rats were randomly divided into 2 groups.

Control group ( $\mathrm{n}=10)$ was fed standard rat chow and drinking water for 8 weeks. Diabetic Control (DC) group $(\mathrm{n}=10)$ :Single dose $\mathrm{STZ}(55 \mathrm{mg} / \mathrm{kg}$ ), was dissolved in sodium citrate buffer (0.1 M,PH 4.5) and carried out intraperitoneal injection (Reinholt et al.). The experiment subjects fasted for 12 hours, then started to be fed with standard rat chow and drinking water after 4 hours. After 2 days, 12 hours of fasting after the application from the tail end with the capillary blood glucose meter (Contour TS Bayer) hand blood glucose levels were measured and the value $250 \mathrm{mg} /$ $\mathrm{dl}$ or above was taken to diabetic group. At the end of the experimental period, rats were anesthetized under ketamine+xylazin and sacrificed by cardiac puncture. Blood samples were taken for biochemical tests of rats. The animals were sacrificed by decapitation. First, the maxillary regions were dissected under ketamine hydrochloride anesthesia. The samples were fixed with neutral buffered formalin solution and decalcified with $5 \%$ ethylene-diamine tetra acetic acid. After preservation, alveolar bone samples were directly dehydrated in a graded series of ethanol and embedded in paraffin wax. Next, 4-6 $\mu \mathrm{m}$ sections were cut with a microtome (Rotatory Microtome, Leica, RM 2265, Germany) and mounted on coated slides. The sections were stained with Haematoxylin and Eosin for observation by light microscopy (Nikon Eclipse 80i).

Immunohistochemical staining. An antigen-retrieval process was performed in citrate buffer solution $(\mathrm{pH} \mathrm{6.0)}$ two times: First for $7 \mathrm{~min}$, and then for $5 \mathrm{~min}$ in a microwave oven at $700 \mathrm{~W}$. They were allowed to cool to room temperature for $30 \mathrm{~min}$ and washed in distilled water for 5 min twice. Endogenous peroxidase activity was blocked in $0.1 \%$ hydrogen peroxide for 15 min. Ultra $\mathrm{V}$ block (Histostain-Plus Kit, Invitrogen, Carlsbad, CA) was applied for $10 \mathrm{~min}$ prior to the application of the primary antibodies (osteonectin antibody, mouse monoclonal, 1/200, Santa Cruz Biotechnology, or osteopontin antibody (mouse monoclonal, 1/200, Santa Cruz Biotechnology) overnight. The secondary antibody (Histostain-Plus Kit, Invitrogen, Carlsbad, CA) was applied for 20 minutes. Then the slides were exposed to streptavidin-peroxidase for $20 \mathrm{~min}$. Diaminobenzidine (DAB, Invitrogen, Carlsbad) was used as a chromogen. Control slides were prepared with same procedure but no primary antibodies. After counterstaining with TrichromMasson stain, slides washed in tap water for $5 \mathrm{~min}$, and in distilled water for $2 \times 5 \mathrm{~min}$, mounted.

\section{Western Blotting}

Cell lysis and protein quantification. The snap frozen bone was grinded to a fine powder in a chilled mortar in the presence of liquid nitrogen. Immediately after grinding, 50 $\mathrm{mg}$ bone powder was transferred into a microcentrifuge tube containing $250 \mu \mathrm{l}$ RIPA lysis buffer $(150 \mathrm{mM} \mathrm{NaCl}, 50 \mathrm{mM}$ Tris, 1 mM EDTA, $1 \%$ (v/v) Triton X-100, $1 \%$ (w/v) sodium deoxycholate, $0.1 \%$ (w/v) SDS, $0.2 \%$ (w/v) sodium fluoride, $0.2 \%(\mathrm{w} / \mathrm{v})$ sodium orthovanadate and $1 \times$ protease inhibitor mixture [CompleteTM EDTA free; Roche Diagnostics] and incubated in ice for $1 \mathrm{~h}$. After incubation, aliquots were snapfrozen in liquid nitrogen and stored $-86^{\circ} \mathrm{C}$. All these steps were performed on ice to minimize protein degradation. Total cellular protein concentration was determined in triplicate using a BCA protein assay according to manufacturer's instructions (Pierce, Thermo scientific). The BCA assay was performed in a 96-well plate using MultiscanTM GO microplate from Thermo Scientific.

SDS-PAGE. All protein samples were resolved by $10 \%$ (v/ v) polyacrylamide gel using a Mini Protean Tetra Cell apparatus system (Bio-Rad). The protein samples were prepared in $1 \times$ SDS loading buffer ( $2 \%(\mathrm{w} / \mathrm{v}) \mathrm{SDS}, 5 \%$ (v/ v) glycerol, $0.01 \%(\mathrm{w} / \mathrm{v})$ bromophenol blue, $8 \%$ (w/v) DTT, which was added just before heating) and heated at $100{ }^{\circ} \mathrm{C}$ for $5 \mathrm{~min}$. The protein samples $(20 \mu \mathrm{g})$ were then loaded on to the $10 \%(\mathrm{v} / \mathrm{v})$ polyacrylamide gel and electrophoresed at $200 \mathrm{~V}$ for $1 \mathrm{~h}$ in a SDS running buffer (2.4 mM Tris, 19.2 $\mathrm{mM}$ glycine, $0.01 \%$ (w/v) SDS).

Membrane transfer and antibody staining. Separated proteins from the SDS-PAGE were transferred onto the PVDF membrane at $100 \mathrm{~V}$ for $1 \mathrm{~h}$ in transfer buffer $(25 \mathrm{mM}$ Tris, $192 \mathrm{mM}$ glycine, $20 \%$ (v/v) methanol, $\mathrm{pH}$ 8.3) using a Criterion Blotter Transfer System (Bio Rad). The membrane 
was then blocked with $5 \%$ (w/v) skim milk powder in PBS$\mathrm{T}(\mathrm{PBS}+0.1 \%(\mathrm{v} / \mathrm{v}) \mathrm{Tween}-20)$ for $1 \mathrm{~h}$ at room temperature. After blocking, the membrane was probed with primary antibodies (anti-osteopontin 1:200 dilution from Santa Cruz, anti-osteonectin 1:200 dilution from Santa Cruz and ant-bactin 1:1000 from Abcam) for $2 \mathrm{~h}$ at room temperature. The membrane was then washed four times over 30 min with PBS-T before probing with horseradish peroxidaseconjugated secondary antibodies in 1:10000 dilutions for 1 $\mathrm{h}$ at room temperature. The membrane was again washed four times over $30 \mathrm{~min}$ with PBS-T. The protein bands were visualized using ECL (Bio-Rad) according to manufacturer's instruction. The images were taken using ChemiDocTM MP (Bio-Rad).

\section{RESULTS}

The serum glucose levels were found statistically significant between the two groups (Table I). The blood glucose levels of diabetic group showed significantly higher compared to control group. The blood glucose concentration in diabetic rats was significantly increased $(\mathrm{p}<0,0001)$.

Diabetes group; periodontal membrane and the dilation of blood vessels, hemorrhage has also been a significant increase in inflammatory cells. Hyperplasia in osteoblast cells was seen leaving collagen fibers alveolar bone in the proximal portion of the periodontal membrane.
It was observed lacunar structure expansion where cells osteocytes. In the diabetes group, osteonectin showed positive expression in periodontal membrane and showed negative expression in osteocytes of alveolar bone. Osteopontin expression in fibroblast cells and periodontal membrane collagen fibrils was positive, and in alveolar cells, osteocytes and bone matrix bone was found positive.

\section{DISCUSSION}

Bone loss is one of the complications in diabetes. It has been proposed that the incidence of bone loss is different between Type $1 \mathrm{DM}$ and Type 2DM (Pacios et al., 2012; Sealand et al., 2013). The worsening of alveolar bone loss observed in diabetic animals with periodontal disease supporting previous studies, since there is a bidirectional relationship between these diseases (Breivik et al., 2005; Kim et al., 2012). In a research C57BL Db/db mice that developed diabetes at six to eight weeks of age to study decreased osteoclastogenesis in bacteria-stimulated bone loss (He et al., 2004). Jiang et al. (2013) reported resorption values of alveolar bone in the upper second molar of four groups of rats at different time points. The rats with periodontal disease (PD) and diabetes mellitus (DM) showed more alveolar bone loss than those with PD alone, DM alone, and control rats at the same time point. The impact of diabetes on bone resorption has yielded contradictory findings, with some studies indicating increased osteoclast activity

Table I. Glucose levels of diabetic control group.

\begin{tabular}{lccccc}
\hline \multicolumn{1}{c}{ Groups } & Mean & Standard & Difference & \multicolumn{2}{c}{ Test } \\
Average of blood glucose & & Deviation & \multicolumn{3}{c}{ statistic } \\
\hline $\begin{array}{l}\text { Non-diabetic group } \\
\text { Diabetic group }\end{array}$ & 97,2857 & 5,3452 & \multirow{2}{*}{306,8572} & 32,032 & $\mathbf{p}<\mathbf{0 , 0 0 0 1}$ \\
\hline
\end{tabular}

Table II. Comparison of histopathological features between the groups.

\begin{tabular}{|c|c|c|c|c|c|c|c|c|}
\hline & & & \multicolumn{5}{|c|}{ Bone degeneration } & \multirow[b]{2}{*}{ Total } \\
\hline & & & nochange & weak & medium & fair & high & \\
\hline \multirow[t]{4}{*}{ Groups } & Control group & Count & 7 & 3 & 0 & 0 & 0 & 10 \\
\hline & & $\%$ within Groups & $70,0 \%$ & $30,0 \%$ & $0 \%$ & $0 \%$ & $0 \%$ & $100,0 \%$ \\
\hline & Diabetes group & Count & 0 & 0 & 4 & 5 & 1 & 10 \\
\hline & & $\%$ within Groups & $0 \%$ & $0 \%$ & $40,0 \%$ & $50,0 \%$ & $10,0 \%$ & $100,0 \%$ \\
\hline \multirow[t]{2}{*}{ Total } & & Count & 7 & 3 & 4 & 5 & 1 & 20 \\
\hline & & $\%$ within Groups & $35,0 \%$ & $15,0 \%$ & $20,0 \%$ & $25,0 \%$ & $5,0 \%$ & $100,0 \%$ \\
\hline
\end{tabular}

Chi-Square $=20,00 ; \mathrm{p}=0,0005$ 

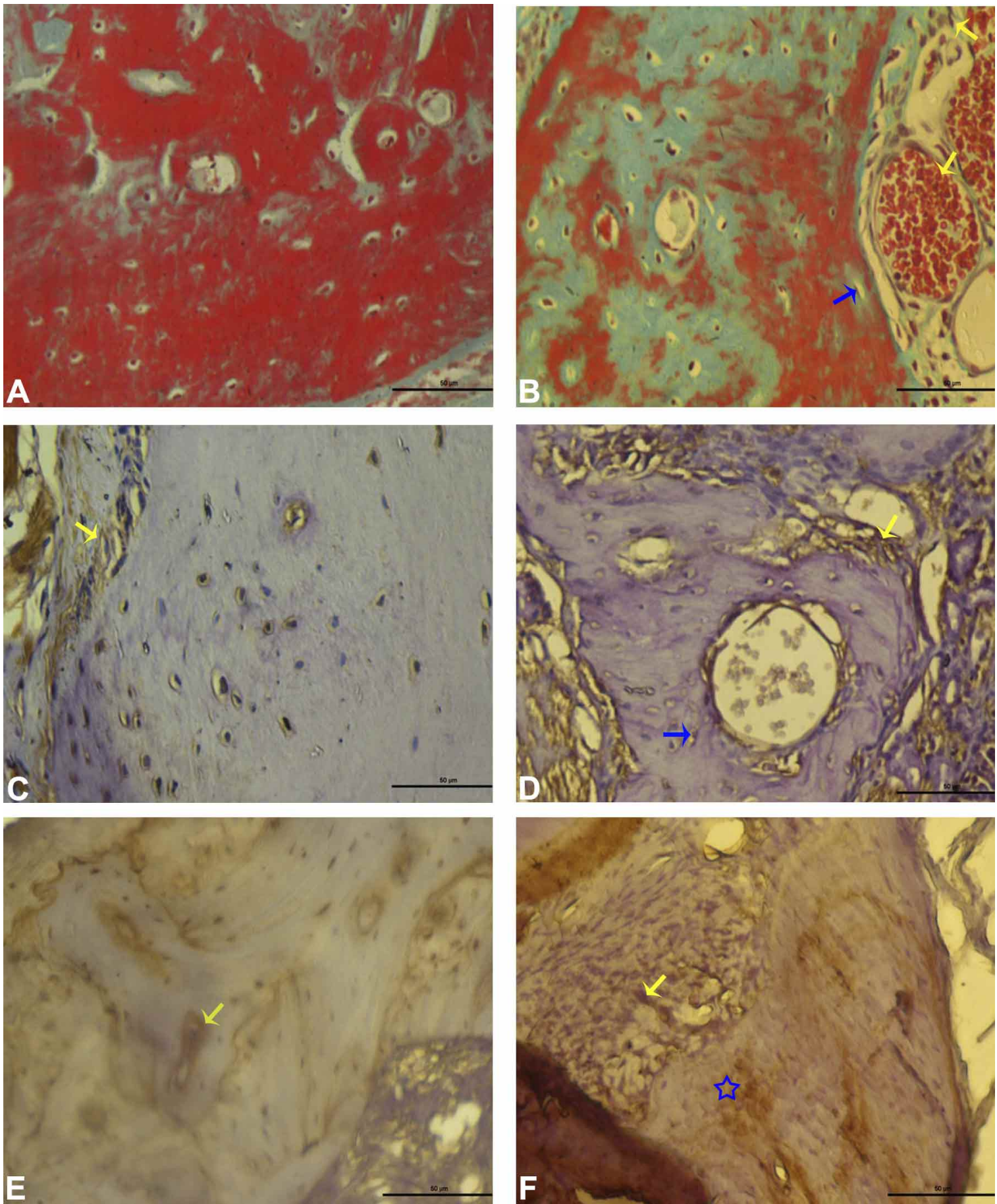

Fig. 1. A- In the control group: Regular collagen fibers appearance and blood vessels in periodontal membrane, normal distribution of osteocytes in alveolar bone Trichrom-Masson staining Bar $50 \mu \mathrm{m}$, B- Diabetes group: Dilatation and hemorrhage in blood vessels and an increase in inflammatory cells of periodontal membrane (yellow arrow). Hyperplasia in osteoblast cells (arrow) separating the collagen fibers in the alveolar bone sections near the periodontal membrane, lacunar structure to expand in osteocytes cells, Trichrom-Masson staining Bar $50 \mu \mathrm{m}$ CD. C- Control group: Weak expression of osteonectin in fibroblast cells and collagen fibers (yellow arrow), of periodontal membrane Osteonectin immun-staining Bar $50 \mu \mathrm{m}$, D- Diabetes group: positive expression of osteonectin in periodontal membrane (yellow arrow), negative expression of osteonectin in osteocyte cells of alveolar bone (blue arrow). Osteonectin immun-staining Bar 50 $\mu \mathrm{m}$, E- Control group: Positive expression of osteopontin in the alveolar bone matrix and haversian channels (arrow). Osteopontin immun-staining Bar 50 $\mu \mathrm{m}$, F- Positive expression of osteopontin in bone matrix (star) and in osteocytes (yellow arrow). Positive osteopontin expression in collagen fibers and fibroblast cells of periodontal membrane (yellow arrow), Osteopontin immun-staining Bar $50 \mu \mathrm{m}$ 


\section{Control DM}

\section{Osteopontin}

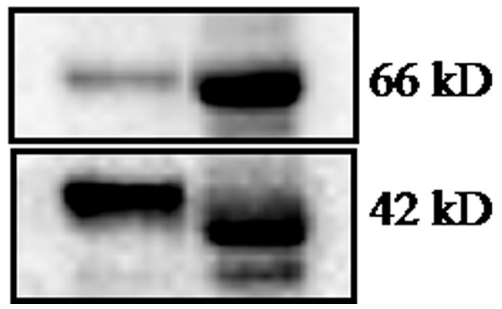

Fig. 2. The expression of osteopontin on bone was dramatically increased in Diabetes Mellitus (DM) Equal amounts of total proteins were run on the gel and analyzed by Western Blotting using antiosteopontin and anti-b-actin antibodies. b-actin was used as a loading control.

\section{Control DM}

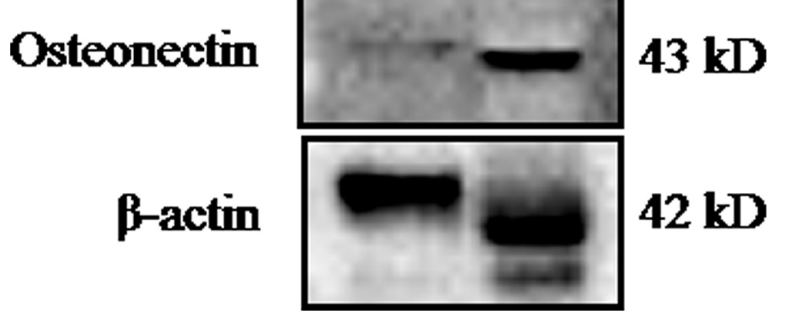

Fig. 3. The expression of osteonectin on bone was dramatically increased in Diabetes Mellitus (DM) Equal amounts of total proteins were run on the gel and analysed by Western Blotting using antiosteonectin and anti-b-actin antibodies. b-actin was used as a loading control.

under perturbation (Gerdhem et al., 2005; Lozano et al., 2009). Diabetes has a significant effect on osteoblasts. It has consistently been noted that diabetes causes a reduction in the number of bone-forming cells (Alikhani et al., 2007). One of the mechanisms through which diabetes affects osteoblasts is elevated apoptosis. For example, AGEs induce osteoblast apoptosis through the MAP kinase pathway (Liu et al., 2006). Diabetes also increases the loss of periodontal ligament (PDL) cells that is induced by periodontal infection by accelerating apoptosis (Isaka et al., 2001). One important aspect of osteonectin in the context of the PDL is the potential for osteonectin to enhance collagen deposition and regeneration of diseased tissue. Periodontal disease is difficult to treat because of the associated bone loss that occurs when the PDL is degraded. Osteonectin production in bones is substantial and is also expressed in cementum, the outer layer of the tooth connecting to the PDL (Delany \& Hankenson, 2009; Zuo et al., 2014). In our study, the periodontal ligament fibers increased collagen in the diabetic group, the hemorrhage was seen as important in inflammation and vascular changes. In the diabetic group compared to the control group, collagen fibers and inflammatory cells in osteonectin increase has led to a change of periodontal structures. However, affect the alveolar bone is thought to induce osteoblast activity in bone loss. In studies of diabetic rats hyperglycaemia has been reported to cause renal OPN production by p38 MAPK pathway (Yan et al.), the patient's blood, diabetes another clinical trial the amount of OPN significantly higher reported (Karamizadeh et al., 2013). Hyperglycemia, working directly with the induction of OPN production of this series, respectively, to support OPN hyperglycemia triggering factors of production. In this study, the expression of osteopontin in the diabetic group showed a significant increase compared to the control group. The increased expression of inflammatory cells in periodontitis is decisive support in previous studies. Periodontitis caused due to the effect of the diabetes, has increased in cell capable of OPN and migration of inflammatory cells. OPN protein is considered as a marker to determine the severity of periodontitis. Diabetes results showed that periodontitis depending on the increase in inflammation inhibits bone formation delaying the development of early bone cell.

YILMAZ, N.; UYSAL, I.; ERATILLA, V.; SEVGI, I.; GÜNES UYSAL, R. F.; ERATILLA, E.; HÜSEYIN, E.; ERSIN, U.; DEVECI, B. \& DEVECI, E. Efectos de la diabetes mellitus inducida por streptozotocina en el hueso alveolar de ratas. Estudio histopatológico e inmunohistoquímico. Int. J. Morphol., 36(1):80$86,2018$.

RESUMEN: El objetivo de este estudio fue investigar los efectos de la diabetes mellitus (DM) sobre el hueso alveolar con métodos histopatológicos e inmunohistoquímicos. Las ratas Wistar se dividieron en dos grupos, grupo control y grupo de diabetes. El grupo control fue alimentado con comida estándar y agua potable durante 8 semanas. La dosis única Streptozotocina (STZ) $(55 \mathrm{mg} /$ $\mathrm{kg}$ ), se disolvió en tampón de citrato de sodio y se introdujo mediante inyección intraperitoneal. El grupo diabetes y el grupo control se compararon en términos de valores de glucosa. La concentración de glucosa en sangre en ratas diabéticas fue significativamente alta $(\mathrm{p}<0,05)$. En el grupo diabetes hubo un aumento significativo de la membrana periodontal y dilatación de los vasos sanguíneos y hemorragia, con un aumento significativo de células inflamatorias. En el grupo diabetes, la osteonectina mostró una expresión positiva en la membrana periodontal además se observó expresión negativa en los osteocitos del hueso alveolar. La expresión de osteopontina en fibroblastos y fibrillas de colágeno en membrana periodontal fue positiva, las células alveolares, osteocitos y hueso de la matriz ósea dio positivo. Los resultados de la diabetes mostraron que existía periodontitis, debido al aumento de la inflamación que inhibió la formación ósea retardando el desarrollo de células óseas tempranas.

PALABRAS CLAVE: Hueso alveolar; Diabetes mellitus; Rata; Osteonectina; Osteopontina. 


\section{REFERENCES}

Al-Maskari, A. Y.; Al-Maskari, M. Y. \& Al-Sudairy, S. Oral manifestations and complications of diabetes mellitus: A review. Sultan Qaboos Univ. Med. J., 11(2):179-86, 2011.

Alikhani, M.; Alikhani, Z.; Boyd, C.; MacLellan, C. M.; Raptis, M.; Liu, R.; Pischon, N.; Trackman, P. C.; Gerstenfeld, L. \& Graves, D. T. Advanced glycation end products stimulate osteoblast apoptosis via the MAP kinase and cytosolic apoptotic pathways. Bone, 40(2):34553, 2007.

Awuti, G.; Younusi, K.; Li, L.; Upur, H. \& Ren, J. Epidemiological survey on the prevalence of periodontitis and diabetes mellitus in Uyghur adults from rural Hotan area in Xinjiang. Exp. Diabetes Res., 2012:758921, 2012

Barrett-Connor, E. \& Holbrook, T. L. Sex differences in osteoporosis in older adults with non-insulin-dependent diabetes mellitus. JAMA, 268(23):3333-7, 1992.

Breivik, T.; Opstad, P. K.; Engstad, R.; Gundersen, G.; Gjermo, P. \& Preus, H. Soluble beta-1,3/1,6-glucan from yeast inhibits experimental periodontal disease in Wistar rats. J. Clin. Periodontol., 32(4):347-52, 2005.

Delany, A. M. \& Hankenson, K. D. Thrombospondin-2 and SPARC/ osteonectin are critical regulators of bone remodeling. J. Cell Commun. Signal, 3(3-4):227-38, 2009.

Gerdhem, P.; Isaksson, A.; Akesson, K. \& Obrant, K. J. Increased bone density and decreased bone turnover, but no evident alteration of fracture susceptibility in elderly women with diabetes mellitus. Osteoporos. Int., 16(12):1506-12, 2005.

Hamann, C.; Kirschner, S.; Günther, K. P. \& Hofbauer, L. C. Bone, sweet bone--osteoporotic fractures in diabetes mellitus. Nat. Rev. Endocrinol., 8(5):297-305, 2012.

He, H.; Liu, R.; Desta, T.; Leone, C.; Gerstenfeld, L. C. \& Graves, D. T. Diabetes causes decreased osteoclastogenesis, reduced bone formation, and enhanced apoptosis ofosteoblastic cells in bacteria stimulated bone loss. Endocrinology, 145(1):447-52, 2004.

Ikeda, T.; Nomura, S.; Yamaguchi, A.; Suda, T. \& Yoshiki, S. In situ hybridization of bone matrix proteins in undecalcified adult rat bone sections. J. Histochem. Cytochem., 40(8):1079-88, 1992.

Isaka, J.; Ohazama, A.; Kobayashi, M.; Nagashima, C.; Takiguchi, T.; Kawasaki, H.; Tachikawa, T. \& Hasegawa, K. Participation of periodontal ligament cells with regeneration of alveolar bone. $J$. Periodontol., 72(3):314-23, 2001.

Jiang, Z. L.; Cui, Y. Q.; Gao; R.; Li, Y.; Fu, Z. C.; Zhang, B. \& Guan, C. C. Study of TNF-a, IL-1b and LPS levels in the gingival crevicular fluid of a rat model of diabetes mellitus and periodontitis. Dis. Markers, 34(5):295-304, 2013.

Karamizadeh, Z.; Kamali Sarvestani, E.; Saki, F.; Karamifar, H.; Amirhakimi, G. H.; Namavar Shooshtarian, M. H. \& Ashkani-Esfahani, S. Investigation of osteopontin levels and genomic variation of osteopontin and its receptors in Type 1 diabetes mellitus. J. Endocrinol. Invest., 36(11):1090-3, 2013.

Kim, Y. S.; Kang, S. J.; Kim, J. W.; Cho, H. R.; Moon, S. B.; Kim, K. Y.; Lee, H. S.; Han, C. H.; Ku, S. K. \& Lee, Y. J. Effects of Polycan, a bglucan, on experimental periodontitis and alveolar bone loss in SpragueDawley rats. J. Periodontal Res., 47(6):800-10, 2012.

Lakschevitz, F.; Aboodi, G.; Tenenbaum, H. \& Glogauer, M. Diabetes and periodontal diseases: interplay and links. Curr. Diabetes Rev., 7(6):4339, 2011.

Liu, R.; Bal, H. S.; Desta, T.; Krothapalli, N.; Alyassi, M.; Luan, Q. \& Graves, D. T. Diabetes enhances periodontal bone loss through enhanced resorption and diminished bone formation. J. Dent. Res., 85(6):510-4, 2006.

Lozano, D.; de Castro, L. F.; Dapía, S.; Andrade-Zapata, I.; Manzarbeitia, F.; Alvarez-Arroyo, M. V.; Gómez-Barrena, E. \& Esbrit, P. Role of parathyroid hormone-related protein in the decreased osteoblast function in diabetes-related osteopenia. Endocrinology, 150(5):2027-35, 2009.

Löe, H. Periodontal disease. The sixth complication of diabetes mellitus. Diabetes Care, 16(1):329-34, 1993.

Ninomiya, T.; Perez-Tilve, D.; Ogawa, D.; Gizard, F.; Zhao, Y.; Heywood, E. B.; Jones, K. L.; Kawamori, R.; Cassis, L. A.; Tschöp, M. H. \& Bruemmer, D. Osteopontin mediates obesity-induced adipose tissue macrophage infiltration and insulin resistance in mice. J. Clin. Invest., 117(10):2877-88, 2007.

Oliver, R. C. \& Tervonen, T. Diabetes--a risk factor for periodontitis in adults? J. Periodontol., 65(5 Suppl.):530-8, 1994.

Pacios, S.; Kang, J.; Galicia, J.; Gluck, K.; Patel, H.; Ovaydi-Mandel, A.; Petrov, S.; Alawi, F. \& Graves, D. T. Diabetes aggravates periodontitis by limiting repair through enhanced inflammation. FASEB $J$., 26(4):1423-30, 2012.

Preshaw, P. M.; Alba, A. L.; Herrera, D.; Jepsen, S.; Konstantinidis, A.; Makrilakis, K. \& Taylor, R. Periodontitis and diabetes: a two-way relationship. Diabetologia, 55(1):21-31, 2012.

Reinholt, F. P.; Hultenby, K.; Oldberg, A. \& Heinegård, D. Osteopontin--a possible anchor of osteoclasts to bone. Proc. Natl. Acad. Sci. U. S. A., 87(12):4473-5, 1990.

Sealand, R.; Razavi, C. \& Adler, R. A. Diabetes mellitus and osteoporosis. Curr. Diab. Rep., 13(3):411-8, 2013.

Sunil, C.; Ignacimuthu, S. \& Agastian, P. Antidiabetic effect of Symplocos cochinchinensis (Lour.) S. Moore. in type 2 diabetic rats. $J$. Ethnopharmacol., 134(2):298-304, 2011.

Yan, X.; Sano, M.; Lu, L.; Wang, W.; Zhang, Q.; Zhang, R.; Wang, L.; Chen, Q.; Fukuda, K. \& Shen, W. Plasma concentrations of osteopontin, but not thrombin-cleaved osteopontin, are associated with the presence and severity of nephropathy and coronary artery disease in patients with type 2 diabetes mellitus. Cardiovasc. Diabetol., 9:70, 2010.

Zuo, L.; Du, Y.; Lu, M.; Gao, J.; Hu, R.; Zhang, S.; Wang, Y.; Zhu, H.; Zhou, Q.; Wei, W. \& Wang, Y. Atorvastatin inhibits hyperglycemiainduced expression of osteopontin in the diabetic rat kidney via the p38 MAPK pathway. Mol. Biol. Rep., 41(4):2551-8, 2014.

\author{
Corresponding author: \\ Dr. Engin Deveci \\ Department of Histology and Embryology \\ Dicle University Faculty of Medicine \\ Diyarbakır \\ TURKEY
}

Email: engindeveci64@gmail.com

Received: 30-05-2017

Accepted: 06-09-2017 